\title{
Headache in the Emergency Department: Which "Red Flags" Predict Head CT Scan Abnormal Findings?
}

\section{Cefaleia no Serviço de Urgência: Que "Sinais de Alarme" Predizem Alterações na TC-CE?}

\author{
(D) Joana Ramos Lopes 1,\#, (D) Mafalda Mendes Pinto 2,\#, (D) Daniela Vieira 1, (D) Joana Jesus Ribeiro 1,3, (D) Isabel Luzeiro ${ }^{1}$ \\ 1-Serviço de Neurologia / Centro Hospitalar e Universitário de Coimbra, Coimbra, Portugal \\ 2-Área Funcional de Neurorradiologia, Serviço de Imagem Médica / Centro Hospitalar e Universitário de Coimbra, Coimbra, Portugal \\ 3-Faculdade de Medicina da Universidade de Coimbra, Coimbra, Portugal
}

DOI: https://doi.org/10.46531/sinapse/AO/200056/2021

\# Co-first authors / Co-primeiros autores

\section{Abstract}

Introduction: Headache accounts for $4 \%$ of all Emergency Department (ED) visits and head-computer tomography scan ( $\mathrm{H}-\mathrm{CT})$ is usually the first method to approach a suspected secondary headache. Screening tools using "red flags" for the appropriate identification of these patients in the ED are of major importance. We aim to identify the differences between headache patients with normal and abnormal $\mathrm{H}-\mathrm{CT}$; to describe the final diagnosis and abnormal H-CT findings; and to recognize which "red flags" could be clinical predictors of abnormal H-CT.

Methods: Retrospective study including adult patients who performed H-CT due to "headache" complaint in the ED. All H-CT were reviewed by two blinded independent neuroradiologists and inter-rater agreement level was determined by Cohen's Kappa coefficient ( $\kappa)$. Binary logistic regression was performed.

Results: A total of 547 patients were included. Age, female gender and previous history of headache were significantly different between patients with normal versus abnormal H-CT. The presence of any "red flag", thunderclap headache, papilledema and history of malignancy were independent predictors of abnormal H-CT. The most frequent final diagnosis was migraine. Only $15.5 \%$ of $\mathrm{H}-\mathrm{CT}$ revealed an abnormality that explain a secondary cause of headache. There was a good level of interobserver agreement in the evaluation of $\mathrm{H}-\mathrm{CT}(\kappa=0.96, \mathrm{Cl} 55 \%=0.99-0.92, p<0.001)$.

Conclusion: The presence of any "red flag", thunderclap headache, papilledema and history of malignancy help to select the appropriate patients with headache for neuroimaging in the ED, avoiding unnecessary exams and optimizing resources in a restricted health care system.

\section{Resumo}

Introdução: A cefaleia é o sintoma responsável por cerca de 4\% das admissões hospitalares no Serviço de Urgência (SU) e a tomografia computorizada crânioencefálica (TC-CE) é normalmente o primeiro meio complementar de diagnóstico utilizado na suspeita de uma cefaleia secundária. Testes de screening recorrendo à presença de "sinais de alarme" para adequadamente identificar estes doentes são de importância fulcral. O nosso objetivo é identificar as diferenças entre doentes com cefaleia com e sem alterações na TC-CE; descrever os diagnósticos finais possíveis dos doentes com cefaleia e os quais os achados em TC-CE; reconhecer que
Informações/Informations: Artigo Original, publicado em Sinapse, Volume 21, Número

1, janeiro-março 2021. Versão eletrónica em www.sinapse.pt Original Article, published in

Sinapse, Volume 21, Number 1 january-march 2021. Electronic version in www.sinapse.pt

(C) Autor (es) (ou seu (s) empregador (es)) e Sinapse 2021. Reutilização permitida de acordo com CC BYNC. Nenhuma reutilização comercial.

(C) Author(s) (or their employer(s)) and Sinapse 2021 Re-use permitted under CC BYNC. No commercial re-use.

Keywords:

Emergency Service, Hospital; Headache/diagnostic imaging; Cefaleias/etiologia;

Tomography, X-Ray Computed.

Palavras-chave:

Cefaleias/diagnóstico por imagem;

Cefaleias/etiologia;

Serviço de Urgência Hospitalar Tomografia Computorizada.

*Autor Correspondente / Corresponding Author:

Joana Ramos Lopes

Praceta Professor Mota Pinto 3000-075 Coimbra, Portugal joanaflopes6@gmail.com

Recebido / Received: 2020-09-29 Aceite / Accepted: 2020-12-19

Publicado / Published: 2021-04-16 
"sinais de alarme" podem ser preditores clínicos da presença de TC-CE anormal.

Métodos: Estudo retrospetivo, incluindo doentes adultos a quem foi realizada uma TC-CE por "cefaleia" no SU. Todos os estudos de imagem foram revistos por dois neurorradiologistas independentes cegos e o nível de concordância inter-observador foi determinado pelo coeficiente Kappa de Cohen (к). Foi realizada regressão logística binária.

Resultados: Foram incluídos 547 doentes. Idade, género feminino e história prévia de cefaleia foram significativamente diferentes entre doentes com TC-CE norma versus anormal. A presença de qualquer "sinal de alarme", cefaleia tipo "thunderclap", papiledema e antecedentes de neoplasia foram preditores independentes de achados anormais na TC-CE. O diagnóstico final mais frequente foi enxaqueca. Apenas 15,5\% das TC-CE revelaram alterações que pudessem explicar uma causa secundária de cefaleia. Houve um bom nível inter-observador na avaliação das TCCE ( $\kappa=0,96, C 195 \%=0,99-0,92, p<0,01)$.

Conclusão: A presença de qualquer "sinal de alarme", cefaleia tipo "thunderclap", papiledema e antecedentes de neoplasia auxiliam na seleção apropriada de doentes com cefaleia a realizar neuroimagem em contexto de urgência, evitando meios complementares desnecessários e permitindo otimizar recursos num sistema de saúde limitado.

\section{Introduction}

On a global scale, $66 \%$ of the adult population experience a life-long headache disorder ${ }^{1}$ and it accounts for approximately $4 \%$ of all Emergency Department (ED) visits, making it one of the most frequent neurological complaints. ${ }^{2-7}$ Headache disorders are divided into two subgroups - primary and secondary - according to the Headache Classification Committee of the International Headache Society (IHS). ${ }^{8}$ Secondary headaches can be due to neurological (e.g. tumours, aneurysms, subarachnoid haemorrhage $(\mathrm{SAH})$, cerebral venous thrombosis (CVT), subdural hematomas, infections, stroke, hydrocephalus) or non-neurological (e.g. systemic infection and acute hypertension) diseases. ${ }^{5,9}$ Although relatively common, an headache can be the main symptom of a life-threatening intracranial pathology, emphasizing the need to distinguish the small number of patients with secondary headaches from the overwhelming majority with benign conditions, especially in the ED. Neuroimaging may have an essential role in this process and should be performed in all the suspected patients. ${ }^{1-4,7,10-12}$ Magnetic resonance imaging (MRI) is preferred and usually yields more specific information, but head-computer tomography scan ( $\mathrm{H}-\mathrm{CT})$ due to its diagnostic performance, availability, non-invasive nature and efficiency is the method of choice to the first approach in the ED. ${ }^{13}$ Although published data included various types of headache, the prevalence of detecting a clinically significant abnormality on neuroimaging is usually below $10 \%$, being higher in acute than non-acute headache patients. $2,11,14$ The paradigmatic diagnosis is the $\mathrm{SAH}$, in which $\mathrm{H}-\mathrm{CT}$ presents a sensitivity of $92.9 \%$ and specificity of $100 \% .^{15}$

The current management of headache patients focuses on the identification of evidence-based "red flags" - signs or symptoms which suggest a significant risk of a secondary etiology and the need for additional workup., ${ }^{1}$-16-19 These "red flags" have been established by clinical experience and large case series, with substantial practice variability among physicians and without clear consensus, with the exception of thunderclap headache. ${ }^{1,11,18,20}$ Other clinical features independently associated with high prevalence of $\mathrm{H}-\mathrm{CT}$ abnormalities were an acute onset headache, associated symptoms, older age and focal neurologic deficits. ${ }^{13,21,22}$ An expert panel on Neurologic Imaging from American College of Radiology ${ }^{23}$ proposed recently an evidence-based guideline to manage neuroimaging in headache patients at specific clinical conditions. $\mathrm{H}-\mathrm{CT}$ is considered appropriate for initial imaging in patients with sudden, severe headache or worst headache of their life; patients with new headache and papilledema 
and those with new or progressively worsening headache with one or more of the following warning signs - subacute head trauma, related activity or event, neurological deficit, known or suspected malignancy, immunosuppressed or immunocompromised state, age of 50 years or older. However, their applicability should be adapted to the routine clinical practice of the ED since it is estimated that up to $35 \%$ of patients were imaged contrary to what is formally indicated. ${ }^{18,24}$ A commonly used screening tool for secondary headaches based on "red flags" is SNOOP4 (systemic symptoms/signs and disease, neurologic symptoms or signs, sudden onset or older age at onset, papilledema, postural, precipitated by Valsalva maneuver, and progressive headache or substantial pattern change), which was published in $2003^{25-27}$ and updated recently to SNNOOPIO with more items. ${ }^{20}$

Accordingly, our aims were: to identify the differences between headache patients with and without abnormal H-CT performed in the ED; to describe the final diagnosis and the abnormal H-CT findings in these patients; and to recognize which "red flags" could be clinical predictors of the abnormal findings on neuroimaging.

\section{Methods}

\section{Participants}

Retrospective transversal study, including consecutive adult patients who performed H-CT due to "headache" complaint in the ED, in a 6-month period (from July to December 2019). All the requests for H-CT were included without regarding the medical specialty where the patient was observed. Patient demographics, clinical data related to headache and medical history were collected. We considered the headache as acute if it lasted up to 3 days, subacute for 4-7 days or chronic for 8 days or more. The "red flags" were collected from clinical history and/or physical examination. The "red flags" considered were: thunderclap headache, altered consciousness status, syncope, fever, change in pattern of headache, night awakening, worsening to Valsalva/decubitus, headache not responding to routine therapy, onset in patients $>50$ years, history of immunosuppression, malignancy, anticoagulation or recent head trauma (last week) and presence of neurological signs (meningism, papilledema and focal signs). The list of "red flags" used in this study was adapted from Do et al, 2019.20

\section{Head CT scan}

All H-CT were obtained using a 64-slice CT scanner
(LightSpeed VCT, GE, CT, USA), with the patient in the supine position, with or without contrast according to clinical information. All H-CT were reviewed and interpreted by two experienced independent neuroradiologists with the initial clinical information, blinded for the final diagnosis. Neuroimaging were classified as normal or abnormal based on-site visual assessment, and the respective pathology was identified.

\section{Final diagnosis}

The final diagnosis was made using 10th edition of the International Classification of Disease (ICDI0) and according to The International Classification of Headache Disorders, $3^{\text {rd }}$ edition (ICHD3), based on retrospective chart review performed by a neurologist. If a headache did not clearly meet criteria for a primary headache and there was no secondary cause, it was classified as headache not otherwise specified (NOS). The secondary causes of headache were considered as extra or intracranial pathologies.

\section{Statistical Analysis}

Demographic and clinical characteristics are presented as frequency and percentage for dichotomous variables and mean \pm standard deviation (SD) for quantitative variables. Comparisons between groups were performed with the Chi-square test (differences between categorical variables), Student\&\#39;s t-test (continuous variables when normally distributed), and Mann-Whitney $U$ test (non-normally distributed continuous variables) when appropriate. Inter-rater agreement level between the two neuroradiologists was determined by Cohen's Kappa coefficient ( $\kappa)$.

Univariate correlations between the altered $\mathrm{H}-\mathrm{CT}$ and the "red flags" and appropriate clinical parameters were determined with Spearman correlation. All variables showing a correlation with abnormal findings at CT scan with $\mathrm{p}<0.05$ were included in the multivariable analysis. Binary logistic regression was used to identify variables independently associated with the presence of altered H-CT, showed by odds ratio and its $95 \%$ confidence interval.

Statistical significance was set for $p<0.05$. All the statistical analyses were made in IBM SPSS Statistics software, version 25 .

\section{Ethics}

The study was approved by the local ethics committee. 


\section{Results}

During the study period, a total of 547 patients were included, 330 individuals were females (60.3\%), with a mean age of $52.7 \pm 20.2$ years. The baseline characteristics are shown in Table 1. Age (5I.4 vs 59.8, $p=0.00 \mathrm{I}$ ), female gender ( $62.6 \%$ vs $48.2 \%, p=0.013)$ and previous history of headache $(24.7 \%$ vs $10.6 \%, p=0.004)$ were significantly different between groups with normal vs. abnormal $\mathrm{H}-\mathrm{CT}$. On the contrary, there were no significant differences concerning sudden onset headache, accompanying clinical symptoms (phono-photophobia, nausea/ vomiting), headache localization and progression. Most patients had a normal neurological examination regardless the $\mathrm{H}-\mathrm{CT}$ result $(82.9 \%$ vs $74.1 \%, p=0.055)$.

"Red flags" were observed in a total of 496 patients
(90.7\%), most of them provided only from clinical history $(\mathrm{N}=373,68.2 \%), 20.3 \%(\mathrm{~N}=\mathrm{II} \mathrm{I})$ showed in clinical history and physical examination and $2.2 \%(\mathrm{~N}=12)$ of the patients showed abnormal findings only at physical examination. The presence of at least one "red flag" was significantly different between patients without or with abnormal $\mathrm{H}-\mathrm{CT}$ findings $(89.6 \%$ vs $96.5 \%, p=0.046)$. No response to routine therapy was the most common "red flag" in both groups, followed by head trauma in last week and changes in pattern of headache. Thunderclap headache $(0.6 \%$ vs $4.7 \%$, $p=0.002)$, history of malignancy ( $4.8 \%$ vs $21.2 \% p<0.001)$, the presence of papilledema ( $0.6 \%$ vs $3.5 \%, p=0.019)$ and focal signs ( $13.0 \%$ vs $21.2 \%, p=0.047)$ were statistically different between patients with normal vs. abnormal neuroimaging. We also verified that there were significant differ-

Table 1. Baseline characteristics of the studied patients.

\begin{tabular}{|c|c|c|c|}
\hline & $\begin{array}{l}\text { With normal } \mathrm{H}-\mathrm{CT} \\
\qquad(\mathrm{N}=462)\end{array}$ & $\begin{array}{l}\text { With abnormal H-CT } \\
\text { findings }(\mathrm{N}=85)\end{array}$ & $p$-value \\
\hline Age, $y$, mean $( \pm S D)$ & $51.4(20.4)$ & $59.8(17.6)$ & 0.001 \\
\hline Female gender, $\mathrm{N}(\%)$ & $289(62.6)$ & $41(48.2)$ & 0.013 \\
\hline Previous history of headache, N (\%) & $114(24.7)$ & $9(10.6)$ & 0.004 \\
\hline Sudden onset of headache, N (\%) & $180(39.0)$ & $30(35.3)$ & 0.523 \\
\hline Phono-photophobia, N (\%) & $122(26.4)$ & $16(18.8)$ & 0.139 \\
\hline Nausea/vomiting, N (\%) & $174(37.7)$ & $23(27.1)$ & 0.062 \\
\hline Localized headache, N (\%) & $212(45.8)$ & $39(45.9)$ & 0.869 \\
\hline $\begin{array}{r}\text { Headache progression, } N(\%) \\
\text { acute } \\
\text { sub-acute } \\
\text { chronic }\end{array}$ & $\begin{array}{l}227(49.1) \\
126(27.3) \\
108(23.4)\end{array}$ & $\begin{array}{c}40(47.1) \\
39(45.9) \\
6(7.1)\end{array}$ & $\begin{array}{l}0.387 \\
0.678 \\
0.245\end{array}$ \\
\hline Normal neurological examination, $\mathrm{N}(\%)$ & $383(82.9)$ & $63(74.1)$ & 0.055 \\
\hline $\begin{array}{r}\text { Presence of any "red flag", N (\%) } \\
\text { "Red flags", N (\%) } \\
\text { Thunderclap headache } \\
\text { Altered consciousness status } \\
\text { Syncope } \\
\text { Fever } \\
\text { Change in pattern of headache } \\
\text { Night awakening } \\
\text { Worsening to Valsalva/decubitus } \\
\text { Onset }>50 \text { years } \\
\text { Onsearing } \\
\text { Headache not responding to routine therapy } \\
\text { History of immunosuppression } \\
\text { Recent head trauma (last week) } \\
\text { History of malignancy } \\
\text { History of anticoagulation } \\
\text { Neurological signs } \\
\text { meningism } \\
\text { papilledema } \\
\text { focal signs }\end{array}$ & $\begin{array}{c}3(0.6) \\
12(2.6) \\
42(9.1) \\
23(5.0) \\
102(22.1) \\
24(5.2) \\
34(7.4) \\
122(26.4) \\
63(26.7) \\
11(2.4) \\
121(26.2) \\
22(4.8) \\
29(6.3) \\
2(0.4) \\
3(0.6) \\
60(13.0)\end{array}$ & $\begin{array}{c}4(4.7) \\
5(5.9) \\
4(4.7) \\
4(4.7) \\
23(27.1) \\
5(5.9) \\
4(4.7) \\
27(31.8) \\
10(16.7) \\
4(4.7) \\
24(28.2) \\
18(21.2) \\
8(9.4) \\
0 \\
3(3.5) \\
18(21.2)\end{array}$ & $\begin{array}{c}0.002 \\
0.109 \\
0.181 \\
0.915 \\
0.315 \\
0.795 \\
0.377 \\
0.308 \\
0.108 \\
0.228 \\
0.695 \\
<0.001 \\
0.291 \\
\\
-- \\
0.019 \\
0.047\end{array}$ \\
\hline $\begin{array}{r}\text { Number of total "red flags", N (\%) } \\
0 \\
1 \\
2 \\
3 \\
>3\end{array}$ & $\begin{array}{l}48(10.4) \\
174(37.7) \\
125(27.0) \\
59(12.8) \\
56(12.1)\end{array}$ & $\begin{array}{c}3(3.5) \\
23(27.1) \\
22(25.9) \\
24(28.2) \\
13(15.3)\end{array}$ & $\begin{array}{c}0.046 \\
0.062 \\
0.854 \\
<0.001 \\
0.419\end{array}$ \\
\hline
\end{tabular}


ences between groups according to the number of total "red flags": patients without "red flags" and normal $\mathrm{H}-\mathrm{CT}$ versus abnormal $\mathrm{H}-\mathrm{CT}$ findings ( $10.4 \%$ vs $3.5 \%, p=0.046)$ and patients with 3 "red flags" and normal $\mathrm{H}-\mathrm{CT}$ versus abnormal $\mathrm{H}$-CT findings ( $\mathrm{I} 2.8 \%$ vs $28.2 \%, p<0.00 \mathrm{I}$ ).

Overall, the most frequent final diagnoses were migraine $(\mathrm{N}=103,18.8 \%)$, headache $\mathrm{NOS}(\mathrm{N}=89,16.3 \%)$ and acute headache attributed to mild head traumatic injury ( $\mathrm{N}=77, \mathrm{I4} .1 \%)$. Supplementary table). Only I5.5\% $(\mathrm{N}=85)$ of $\mathrm{H}-\mathrm{CT}$ revealed an abnormality that explain a secondary cause of headache. All the findings and respective frequency are showed in Table 2. Acute rhinosinusitis was responsible for $31.7 \%$ of the cases $(N=27)$; space-

Table 2. Abnormal H-CT findings.

\begin{tabular}{|l|r|}
\hline \multicolumn{2}{|c|}{ Abnormal H-CT findings (N=85) } \\
\hline Acute rhinosinusitis & $27(31.7 \%)$ \\
\hline Space-occupying lesion & $17(20.0 \%)$ \\
\hline ASDH + traumatic SAH & $15(17.6 \%)$ \\
\hline Subgaleal hematoma & $10(11.8 \%)$ \\
\hline Facial structures fracture & $3(3.5 \%)$ \\
\hline Acute hydrocephalus & $3(3.5 \%)$ \\
\hline Non-traumatic intracerebral haemorrhage & $3(3.5 \%)$ \\
\hline Non-traumatic SAH & $3(3.5 \%)$ \\
\hline Pos-surgery suboccipital CSF collection & $2(2.4 \%)$ \\
\hline Chiari malformation type 1 & $1(1.2 \%)$ \\
\hline CVT & $1(1.2 \%)$ \\
\hline
\end{tabular}

ASDH: acute subdural haemorrhage; SAH: subarachnoid haemorrhage; CSF: cerebrospinal fluid; CVT: cerebral venous thrombosis.

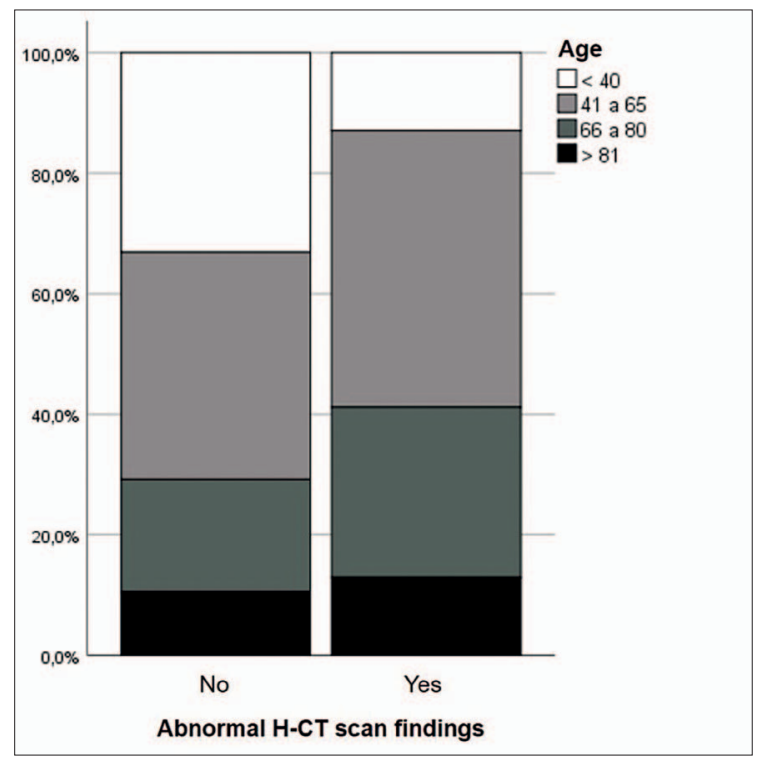

Figure 1. Age distribution of patients without and with abnormal H-CT findings.

occupying lesion was the second most frequent $(\mathrm{N}=17$, $20.0 \%)$. The pathological findings on $\mathrm{H}-\mathrm{CT}$ were more frequent at older ages (Fig. 1). There was a good level of interobserver agreement in the evaluation of $\mathrm{H}-\mathrm{CT}$ with $\kappa=0.96(C 195 \%=0.99-0.92, p<0.00 \mathrm{I})$.

Multivariable analysis (Fig. 2) showed thunderclap headache (OR: 7.78, $\mathrm{Cl} 95 \%=1.709-35.427, p=0.002$ ), papilledema (OR: $5.76, \mathrm{Cl} 95 \%=1.143-39.055, p=0.017$ ) and history of malignancy (OR: 4.38, Cl95\% $=2.212$ 8.666, $p<0.00 \mathrm{I})$ as independent predictors of abnormal H-CT. Also, the presence of any "red flag" was a significant predictor for abnormal findings in H-CT (OR: 3.17, $C 195 \%=0.964-10.419, p=0.046)$.

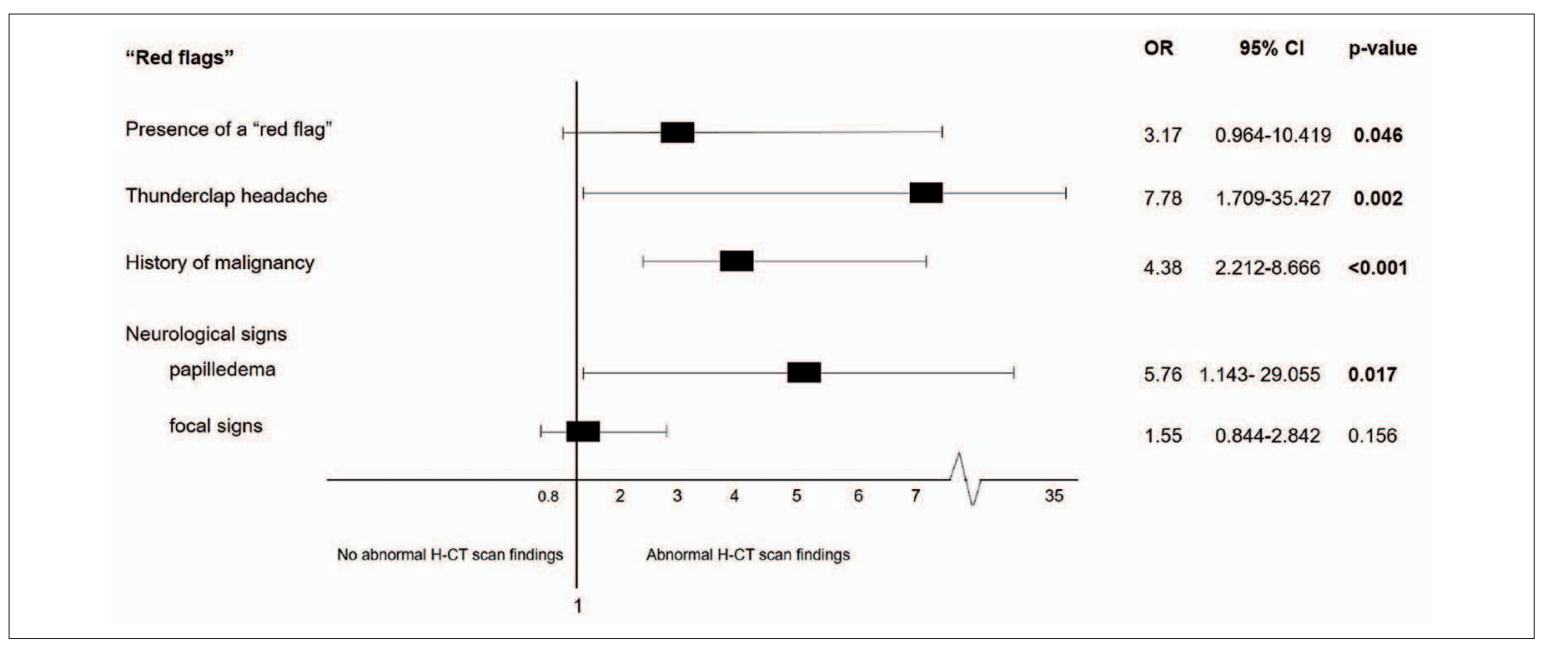

Figure 2. Multivariable analysis for predictors of abnormal H-CT findings. 


\section{Discussion}

In our study, we identified the differences between headache patients with normal vs. abnormal $\mathrm{H}-\mathrm{CT}$, highlighting the respective "red flags" that can predict aberrant $\mathrm{H}-\mathrm{CT}$ findings, to contribute to the improvement of the current management of these patients in the ED.

Patients with normal H-CT were younger, mainly female and presented a previous history of headache more frequently. According to previous published studies, primary headaches (migraine or tension-type headache) are the most frequent causes of headache in the ED, affects more women and younger population, and need recurrent episodes to fulfill ICHD3 diagnostic criteria. ${ }^{2,7,15,17}$ Although an abnormal neurological examination is more likely to be associated to the presence of a significant brain pathology detected by neuroimaging, ${ }^{10,15}$ in our study we did not find significant differences between patients with and without normal $\mathrm{H}-\mathrm{CT}$. It is important to emphasize that the neurological evaluation was not standardized, and the patients included in our study were evaluated by physicians with different clinical expertise and could have an incomplete examination. However, similar results have already been reported by other authors, showing that this is not a linear relationship. Goldstein et al, 2018 12 showed that a normal neurologic examination, even when performed by a neurologist, does not rule out a significant secondary cause for headache. Also, Munoz-Ceron et al, 20197 referred that an abnormal neurological examination was not different between primary and non-primary headache etiologies.

Globally, the most frequent final diagnoses were episodic migraine and headache NOS, like the majority of the published cohorts. ${ }^{2,7, I 1,24}$ Interestingly, only 15.5\% of $\mathrm{H}-\mathrm{CT}$ revealed a secondary cause that justified the headache complaint. Our study found a higher variability in the imagiological causes of secondary headache comparing to that documented by other authors, with acute rhinosinusitis being the most frequent. $2,9,10,21$

Despite the low percentage of abnormal H-CT results, our results suggest that in the presence of a "red flag" neuroimaging should be performed to a patient with headache in the ED, since it was a significant predictor of abnormalities in $\mathrm{H}-\mathrm{CT}$. Among the "red flags", thunderclap headache, papilledema and history of malignancy were independent predictors of abnormal $\mathrm{H}-\mathrm{CT}$ findings. These data reinforce the paramount importance of the prompt identification of these red flags in the clinical practice in the ED. Indeed, thunderclap headache is the most frequent described "red flag" in literature and is known for its link to SAH. ${ }^{10,11,18,20}$ Other important "red flags" described in previous studies, which complement our results, are focal neurologic deficits, ${ }^{9,13,19,21,22}$ headache with acute onset, ${ }^{13,21,22}$ associated symptoms (nausea and/or vomiting), ${ }^{13,21}$ derangements in coagulation profile,,$^{13}$ and new-onset in immunosuppressed patients. ${ }^{7,10}$ Locker et al, 2004 ${ }^{28}$ also described systolic blood pressure greater than 160 $\mathrm{mmHg}$, abnormal respiratory examination, pain with a stabbing headache and pain in the orbit as clinical features that increase the probability of the presence of a secondary etiology. Although a headache with onset after 50 years old was not a predictor for abnormal $\mathrm{H}-\mathrm{CT}$ findings, pathological findings on $\mathrm{H}-\mathrm{CT}$ were more frequent at older ages, as it is widely referred in published data, $1,2,7,10,11,13,21,22$ which makes neuroimaging strongly recommended in these age groups. In fact, Starling et al, $2018^{26}$ indicate a higher risk of secondary headaches in older adults, with a potentially life-threatening causes being increased 10 -fold in those 65 years and older.

Validated screening tools based on "red flags" for a reliable identification of a secondary headache are essential in the ED. We hope that our findings will contribute to refine these screening tools, increasing their applicability in routine clinical practice. Future progress of clinical practice will build on the use of algorithms to predict which patients will benefit from $\mathrm{H}-\mathrm{CT}$. Bent et al, $2015^{22}$ proposed that only patients with focal neurologic deficit (major risk factor) or 2 or more of the five minor risk factors (altered mental status, nausea/vomiting, history of malignancy, coagulopathy and age) will benefit of $\mathrm{H}-\mathrm{CT}$, reducing its utilization by $34 \%$ with only a small decrease in sensitivity (98\%). The selective use of H-CT in headache patients is relevant since it carry some risks, including false reassurance from an inadequate study, a potential reaction to contrast if it was necessary (allergic reaction and renal dysfunction), radiation exposure and a limited cost-efficacy. ${ }^{10,14,17}$

There are some limitations to the present study. First, it is a retrospective and a single center study and did not include ED patients with headache complaint who did not undergo H-CT. Furthermore, patient assessment, the registration of the clinical data, including headache characteristics, and physical examinations were not standardized and were obtained by distinct providers 
with different clinical expertise. The size of the study population was smaller comparing to other published

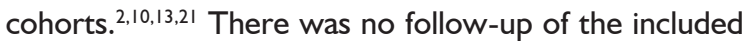
patients, so we cannot exclude a diagnosis of secondary headache posterior to the assessment moment. Among diseases that can be missed on $\mathrm{H}-\mathrm{CT}$, the most relevant are an arterial dissection, an arteriovenous malformation, a SAH (before 72 hours), a central nervous system vasculitis, a posterior fossa neoplasm, a meningeal carcinomatosis or idiopathic hypertrophic pachymeningitis. ${ }^{27}$ This study was not designed to determine the positive predictive value of individual "red flags".

In conclusion, it is fundamental the correct recognition of "red flags" in the clinical history and physical examination of patients with headache in the ED. Thunderclap headache, papilledema and history of malignancy are clinical predictors of secondary causes of headache, and may help to select the appropriate patients for neuroimaging, avoiding unnecessary exams and optimizing resources in a restricted health care system.

\section{Responsabilidades Éticas}

Conflitos de Interesse: Os autores declaram a inexistência de conflitos de interesse na realização do presente trabalho.

Fontes de Financiamento: Não existiram fontes externas de financiamento para a realização deste artigo.

Confidencialidade dos Dados: Os autores declaram ter seguido os protocolos da sua instituição acerca da publicação dos dados de doentes.

Proteção de Pessoas e Animais: Os autores declaram que os procedimentos seguidos estavam de acordo com os regulamentos estabelecidos pelos responsáveis da Comissão de Investigação Clínica e Ética e de acordo com a Declaração de Helsínquia da Associação Médica Mundial.

Proveniência e Revisão por Pares: Não comissionado; revisão externa por pares.

\section{Ethical Disclosures}

Conflicts of interest: The authors have no conflicts of interest to declare.

Financing Support: This work has not received any contribution, grant or scholarship

Confidentiality of Data: The authors declare that they have followed the protocols of their work center on the publication of data from patients.

Protection of Human and Animal Subjects: The authors declare that the procedures followed were in accordance with the regulations of the relevant clinical research ethics committee and with those of the Code of Ethics of the World Medical Association (Declaration of Helsinki).

Provenance and Peer Review: Not commissioned; externally peer reviewed.

\section{References / Referências}

1. Mackenzie MJ, Hiranandani R, Wang D, Fung T, Lang E. Determinants of Computed Tomography Head Scan Ordering for Patients with Low-Risk Headache in the Emergency Department. Cureus. 2017;9:e1760.

2. Goldstein J, Jr CC, Pelletier A, Edlow J. Headache in United
States Emergency Departments: Demographics, Work-Up and Frequency of Pathological Diagnoses. Cephalalgia. 2006;26:684-90.

3. Kahkeshani K, Sheikh HU. Headache in the Emergency Room. US Neurol. 2017;13:94-8.

4. Cutrer FM, li FJW, Edlow JA. Evaluation of the adult with nontraumatic headache in the emergency department. UpToDate. 2020. [accessed Jun 2020] Available from: https:// www.uptodate.com/contents/evaluation-of-the-adult-withnontraumatic-headache-in-the-emergency-department

5. Jamieson DG, Hargreaves R. The Role of Neuroimaging in Headache. J Neuroimaging. 2002;12:42-51.

6. Heetderks-Fong E. Appropriateness Criteria for Neuroimaging of Adult Headache Patients in the Emergency Department: How Are We Doing? Adv Emerg Nurs J. 2019;41:172-82. doi: 10.1097/TME.0000000000000240.

7. Munoz-Ceron J, Marin-Careaga V, Pena L, Mutis J, Ortiz G. Headache at the Emergency Room: Etiologies, Diagnostic Usefulness of the ICHD 3 Criteria, Red and Green Flags. PLoS One. 2019;7: e0208728. doi: 10.1371/journal. pone.0208728.

8. Headache Classification Committee of the International Headache Society (IHS) The International Classification of Headache Disorders, 3rd edition. Cephalalgia. 2018;38:1211. doi: $10.1177 / 0333102417738202$.

9. Aygun D, Bildik F. Clinical Warning Criteria in Evaluation by Computed Tomography the Secondary Neurological Headaches in Adults. Eur J Neurol. 2003;10:437-42.

10. Jordan YJ, Lightfoote JB, Jordan JE. Computed Tomography Imaging in the Management of Headache in the Emergency Department: Cost Efficacy and Policy Implications. J Natl Med Assoc. 2009;101:331-5.

11. Giamberardino M, Giannapia A, Raffaele C, Martina G, Martelletti P. Acute Headache Management in Emergency Department. A Narrative Review. Intern Emerg Med. 2020;15:109-17. doi: 10.1007/s11739-019-02266-2.

12. Goldstein L, Laytman T, Steiner I. Is Head Computerized Tomography Indicated for the Workup of Headache in Patients With Intact Neurological Examination. Eur Neurol. 2018;80:341-4. doi: 10.1159/000496805.

13. Wang $X$, You JJ. Head CT for Nontrauma Patients in the Emergency Department: Clinical Predictors of Abnormal Findings. Radiology. 2013;266:783-90.

14. Jang YE, Cho EY, Choi HY, Kim SM, Park HY. Diagnostic Neuroimaging in Headache Patients: A Systematic Review and Meta-Analysis. Psychiatry Investig. 2019;16:407-18. doi: 10.30773/pi.2019.04.11.

15. Holle $D$, Obermann $M$. The role of neuroimaging in the diagnosis of headache disorders. Ther Adv Neurol Disord. 2013;6:369-74.

16. Detsky ME, Mcdonald DR, Baerlocher MO, Tomlinson GA, Mccrory DC, Booth CM. Does This Patient With Headache Have a Migraine or Need Neuroimaging? JAMA 2006:296:1274-83.

17. Micieli A, Kingston W. An Approach to Identifying Headache Patients That Require Neuroimaging. Front Public Heal. 2019;7:1-6.

18. Young NP, Elrashidi MY, Mckie PM, Ebbert JO. Neuroimaging Utilization and Findings in Headache Outpatients: Significance of Red and Yellow Flags. Cephalalgia. 2018;38:1841-8. doi: 10.1177/0333102418758282.

19. Sobri M, AC Lamont, NA Alias, MN Win. Red Flags in Patients Presenting With Headache: Clinical Indications for Neuroimaging. Br J Radiol. 2003;76(908):532-5.

20. Do TP, Remmers A, Schytz HW, Schankin C, Nelson SE, Obermann M, et al. Red and Orange Flags for Secondary Headaches in Clinical Practice: SNNOOP10 List. Neurology. 2019;92:134-44. doi: 10.1212/WNL.0000000000006697.

21. Ramirez-Lassepas M, Espinosa C, Cicero J, Johnston K, Cipolle R, Barber D. Predictors of Intracranial Pathologic Findings in Patients Who Seek Emergency Care Because of Headache. Arch Neurol. 1997;54:1506-9.

22. Bent $C$, Lee PS, Shen PY, Bang $H$, Bobinski M. Clinical 
Scoring System May Improve Yield of Head CT of NonTrauma Emergency Department Patients. Emerg Radiol. 2015;22;511-6.

23. Imaging, Expert Panel on Neurologic: Whitehead MT, Cardenas AM et al. ACR Appropriateness Criteria Headache. J Am Coll Radiol. 2019;16:S364-77. doi: 10.1016/j. jacr.2019.05.030.

24. Callaghan BC, Kerber KA, Pace RJ, Skolarus L, Cooper W, Burke JF. Headache neuroimaging: routine testing when guidelines recommend against them. Cephalalgia. 2015;35:1144-52. doi: 10.1177/0333102415572918.

25. Dodick DW. Pearls: Headache. Semin Neurol. 2010;30:74-
81. doi: $10.1055 / \mathrm{s}-0029-1245000$.

26. Starling AJ. Diagnosis and management of headache in older adults. Mayo Clin Proc. 2018;93:252-62. doi: 10.1016/j. mayocp.2017.12.002.

27. Ravishankar K. "WHICH Headache to Investigate, WHEN, and HOW?" Headache. 2016;56:1685-97. doi: 10.1111/ head.12998.

28. Locker T, Mason S, Rigby A. Headache Management - Are We Doing Enough? An Observational Study of Patients Presenting With Headache to the Emergency Department. Emerg Med J. 2004;21:327-32. 